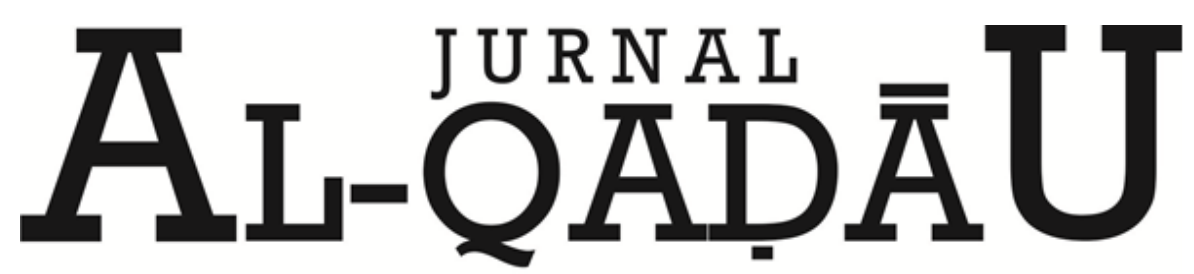

PERADILAN dan HUKUM KELUARGA ISLAM

\title{
Poligami dalam Perspektif Hukum Islam
}

The Polygamy in the Perspectif of Islamic Law

Andi Intan Cahyani

Dosen Fakultas Syariah dan Hukum UIN Alauddin Makassar

Email: andiintan.cahyani@gmail.com

\begin{tabular}{|c|c|}
\hline $\begin{array}{c}\text { Info } \\
\text { Artikel }\end{array}$ & Abstract \\
\hline $\begin{array}{l}\text { Diterima } \\
24 \\
\text { September } \\
2018\end{array}$ & $\begin{array}{l}\text { Penelitian ini membahas tentang Poligami dalam Prespektif Hukum } \\
\text { Islam. Poligami merupakan laki-laki memiliki istri lebih dari satu sampai } \\
\text { empat orang. Dalam pandangan Islam, poligami boleh dilakukan jika } \\
\text { memenuhi syarat yang sudah jelas dalam al-Qur'an yaitu, mampu berlaku } \\
\text { adil. Adil yang dimaksud disini meliputi beberapa bagian, yaitu: adil } \\
\text { dalam pembagian waktu, adil dalam nafkah, adil dalam tempat tinggal } \\
\text { dan adil dalam biaya anak. Poligami Rasulullah berbeda dengan } \\
\text { poligami yang kita lihat sekarang ini. Praktek poligami Rasulullah di sini } \\
\text { bukan berlandaskan ebutuhan biologis, tetapi ada beberapa } \\
\text { pertimbangan diantaranya ingin memberi kehormatan untuk janda, } \\
\text { mengangkat derajat para janda dan wanita yang menawarkan dirinya } \\
\text { untuk dinikahi. Dalam masa sekarang poligami hanya berlandaskan } \\
\text { kebutuhan biologis, dan melupakan unsur keadilan di dalamnya. } \\
\text { Kata Kunci: Poligami, Hukum Islam }\end{array}$ \\
\hline $\begin{array}{l}\text { Revisi II } \\
06 \\
\text { Nopember } \\
2018\end{array}$ & $\begin{array}{l}\text { This study discusses polygamy in the perspective of Islamic law. Polygamy } \\
\text { is a man who has a wife more than one up to four people. In Islamic view, } \\
\text { polygamy can be done if it meets the requirements that are clearly } \\
\text { mentioned in the Qur'an, that is, being able to be fair. The fair referred } \\
\text { includes several parts, namely: fair in the shared time, fair in living, fair } \\
\text { in the place of residence and fair in the cost of the child. Rasulullah's } \\
\text { polygamy is different from the polygamy phenomena that we face today. } \\
\text { The practice of the Prophet's polygamy is not based on biological needs, } \\
\text { but there are several considerations including wanting to honor the } \\
\text { widow, raising the degree of widows and women who offer herself to be } \\
\text { married. In the present, polygamy is based solely on biological needs, and } \\
\text { lose the element of justice in it. }\end{array}$ \\
\hline
\end{tabular}

Keywords: Polygamy, Islamic Law 


\section{A. PENDAHULUAN}

Menikah adalah salah satu Sunnah Rasulullah saw. yang tergolong penting. Bahkan Rasulullah pernah berkata akan mengeluarkan seseorang dari barisan umatnya jika membenci atau tidak mau untuk menikah. Oleh sebab itu, dalam Islam tidak ada yang namanya pemisahan diri dengan kelompok tertentu yang memiliki jenis kelamin yang berbeda. Dengan demikian, Islam sangat melarang adanya sesorang yang menghindar untuk menikah, baik itu laki atau perempuan yang dengan sengaja menghindar untuk dinikahi karena sebab-sebab tertentu. Misalnya, seorang wanita ingin tetap dalam kesucian. ${ }^{1}$

Kata poligami tiselalu saja dikaitkan dengan apa yang dilakukan oleh Nabi saw. beliau berpoligami dengan cara yang dibenarkan oleh syariat dengan pengaplikasian ayat-ayat dalam al-Qur'an yang mengatakan laki-laki boleh memiliki istri lebih dari satu. Dengan adanya ayat tersebut yang menjadi pegangan bagi kaum laki-laki untuk melakukan poligami. Tetapi, banyak diantara umat Rasulullah saw. yang kurang atau tidak mengerti sama sekali akan makna poligami yang benar, sehingga menjadikan poligama hanya untuk melampiaskan kebutuhan seksual saja dan menghilangkan tujuan mulia yang ada di dalamnya. ${ }^{2}$

Persoalan yang paling banyak dibicarakan dalam lingkup perkawinan adalah poligami. Poligami ini memang sangat kontroversial, ada satu sisi menolak poligami dengan sandaran berbagai macam, baik itu yang bersifat normatif, psikologis bahkan banyak pula yang mengaitkan dengan munculnya ketidakadilan gender. Banyak pula penulis-penulis barat yang mengatakan bahwa ajaran poligami ini awalnya bersumber dari agama Islam yang sangat diskriminatif terhadap kaum perempuan. Kemudian disisi lain, poligami ini malah dikampanyekan karena mereka menganggap memiliki sandaran normatif yang jelas dan tegas. Kelompok yang pro tersebut memandang dengan adanya pembolehan tentang poligami ini bisa menjadi alternatif untuk mengurangi perselingkuhan dan prostitusi yang merajalela. ${ }^{3}$ Bredasarkan uraian di atas maka pokok permaslahan dalam penelitian ini adalah bagaimana poligami dalam prespektif hukum Islam.

\section{B. METODE PENELITIAN}

Jenis penelitian ini merupakan library research (penelitian kepustakaan) merupakan Pengumpulan data yang diperoleh langsung dari berbagai literatur. Metode pengumpulan bersumber data-data yang diperoleh dari berbagai literatur, peraturan perundang-undangan, pendapat para ahli hukum, dokumen serta tulisan lain yang terkait materi yang dibahas sebagai penunjang. Data-data yang diperoleh dianalisis secara kualitatif kemudian disajikan secara deskriptif yaitu menguraikan, menggambarkan, dan menjelaskan sesuai dengan permasalahan yang erat kaitannya dengan penelitian ini.

${ }^{1}$ Muhammad Yahya, Poligami Dalam Perspektif Nabi saw (Makassar: Alauddin University Perss, 2013), h. 1.

${ }^{2}$ Agus Mustofa, Poligami Yuuk! (Surabaya: PADMA Press), h. 225.

${ }^{3}$ Amir Nuruddin dan Azhari Akmal Tarigan, Hukum Perdata Islam di Indonesia: Studi Kritis Perkembangan Hukum Islam dari Fikih, UU No. $1 / 1974$ sampai KHI (Cet. V. Jakarta: Kencana Prenadamedia Group, 2014), h. 156. 


\section{PEMBAHASAN}

\section{Sejarah Poligami}

Dari wikipedia dijelaskan bahwa poligami merupakan praktik pernikahan kepada lebih dari satu suami atau istri (sesuai dengan jenis kelamin orang bersangkutan). Perkawinan yang dilakukan oleh laki-laki kepada lebih dari satu wanita merupakan pemahaman umum tentang poligami, dengan arti bahwa laki-laki dalam berumah tangga harus membagi cinta dan kasih sayangnya kepada beberapa istri yang dimiliki, dan hal ini mampu mengundang tanggapan positif dan negatif orang lain tehadap moral yang dimiliki oleh pelaku poligami. ${ }^{4}$

Konsep poligami (ta'addud al-zaujāt) dalam ilmu fikih secara umum dipahami sebagai seorang suami dalam waktu bersamaan yang mengumpulkan dua sampai empat istri. Poligami tidak dapat diketahui secara pasti awal mula kemunculannya. Sejak ribuan tahun silam, sebelum datangnya Islam poligami sudah menjadi tradsi yang dianggap wajar. ${ }^{5}$

Banyaknya bukti yang menajdi dasar dikatakannya poligami bukanlah ajaran dari agama Islam. Negara-negara yang melakukan praktik poligami seperti Rusia, Yugosliva, Cekoslovakia, Jerman, Belgia, Belanda, Denmark, Swedia dan Inggris. Demikian juga beberapa dari bangsa Timur seperti bangsa Ibrani dan Arab. Dari kesemuanya itu menurut catatan sejarah melakukan praktik poligami. Jadi para penulis barat yang mengklaim bahwa poligami berawal dari ajaran agama Islam tidaklah benar. Sebab, negara-negara yang disebutkan di atas melakukan poligami jauh sebelum Islam datang di muka bumi ini dan bahkan berkembang pesat di negeri Afrika, India, Cina dan Jepang yang pada dasarnya tidak menganut agama Islam. ${ }^{6}$

Poligami sendiri berasal dari bahasa Yunani. Kata ini merupakan penggalan kata poli dan polus yang artinya banyak, dan kata gemein atau gamos, yang artinya kawin atau perkawinan. Maka, ketika kedua kata ini digabungkan akan berarti suatu perkawinan yang banyak. Dalam Islam, arti dari poligami adalah perkawinan yang dilakukan lebih dari satu dengan memiliki batasan yang telah ditentukan, yang pada umumnya dipahami sampai dengan empat wanita. Ada pula yang memahami bahwa poligami dalam Islam bisa sampai Sembilan atau lebih. Akan tetapi, poligami dengan batasan sampai dengan empat istri ini lebih umum dipahami dengan dukungan dari sejarah, sebab Rasulullah saw. Melarang umatnya melakukan pernikahan lebih dari empat wanita. ${ }^{7}$

Agama Nasrani pada awalnya tidak melarang atau mengharamkan poligami, landasan diperbolehkannya karena dalam kitab Injil tidak satupun ayat yang melarang keras melakukan poligami. Berbeda dengan agama Yunani dan Romawi yang memang dari awal memarang melakukan poligami. Setelah mereka memeluk agama Kristen, mereka tetap menjalankan monogami yang dianggap sebagai ajaran dari nenek monyang mereka terdahulu yang melarang poligami. Oleh karena itu, orang-orang Kristen bangsa Eropa tetap melaksanakan perkawinan dengan asas monogami. Dengan demikian, ajaran mengenaai monogami ini bukan murni dari agama Kristen, melainkan

${ }^{4}$ Muhammad Yahya, Poligami Dalam Perspektif Nabi saw, h. 3.

${ }^{5}$ Nasaruddin Umar, Ketika fikih Membela Perempuan (Jakarta: PT. Gramedia, 2014), h. 126.

${ }^{6}$ Alhamdani, Risalah Nikah: Hukum Perkawinan Islam (Yogyakarta: PT. Raja Grafindo Persada, 1972), h. 79-80.

${ }^{7}$ Muhammad Yahya, Poligami Dalam Perspektif Nabi saw, h. 3. 
ajaran lama yang mereka anut. Gereja kemudian menjadikan larangan poligami sebagai peraturan dan ajaran dari agama, meskipun pada dasarnya dalam kitab Injil tidak disebutkan larangan poligami. ${ }^{8}$

Poligami tidaklah serta merta diperbolehkan dalam Islam. Islam memiliki batasan dan syarat yang ketat kepada seorang yang hendak melakukan poligami, diantaranya boleh melakukan poligami sampai dengan empat istri apabila ia bener-benar mampu dalam berlaku adil terhadap istri-istrinya yang menyangkut persoalan nafkah, tempat tinggal dan pembagian waktu. Islam menekankan dengan tegas, apabila dikhawatirkan untuk tidak bisa berlaku adil maka cukuplah dengan satu istri. Allah berfirman dalam QS. al-Nisā/4: 3

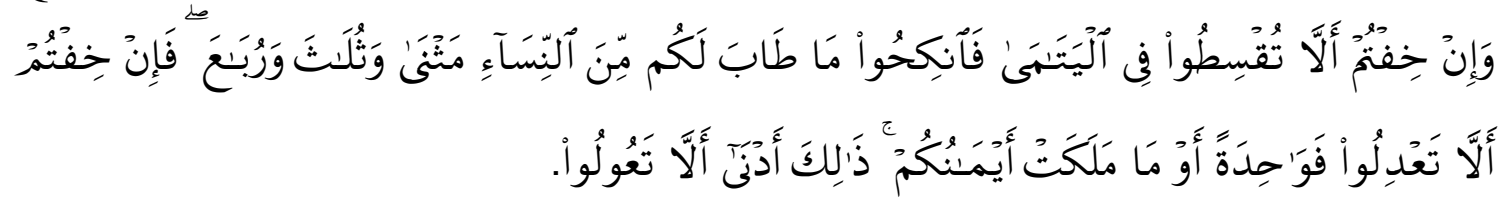

Terjemahnya:

"Apabila kamu tajut tidak dapat berlaku adil terhadap perempuan yatim (yang kamu kawini) maka kawinilah wanita-wanita (lain) yang kamu senangi, dua, tiga atau empat. Kemudian jika kamu takut tidak dapat berlaku adil maka kawinilah seorang saja, atau budak-budakmu. Yang demikian itu lebih dekat untuk tidak berlaku aniaya". 9

Maksud adil terhadap istri adalah sekadar yang dapat dilakukan oleh seseorang yang dapat berlaku adil, misalnya dalam soal membagi waktu, nafkah, pakaian dan tempat tinggal. ${ }^{10}$

\section{Poligami Rasulullah saw}

Praktik poligami yang dilakukan oleh Rasulullah saw. sangat jauh berbeda dengan poligami yang terjadi sekarang ini. Oleh karena itu, untuk bisa memahami dengan jelas maksud dan tujuan dari praktik poligami Rasulullah dapat dilihat dari persoalan atau sebab mengapa beliau berpoligami. Diantaranya: ${ }^{11}$

Pertama, Rasulullah diutus untuk menyebarkan kasih dan sayang kepada seluruh alam oleh Allah swt. Sejalan firman Allah dalam QS. al-Anbiyā (21):107

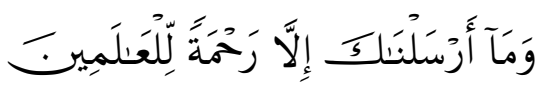

Terjemahnya:

Dan tiadalah Kami mengutus kamu, melainkan untuk (menjadi) rahmat bagi semesta alam. ${ }^{12}$

Kedua, Rasulullah diutus menjadi contoh suri tauladan untuk umat manusia. Ini dijelaskn dalam QS. al-Ahzab (33): 21

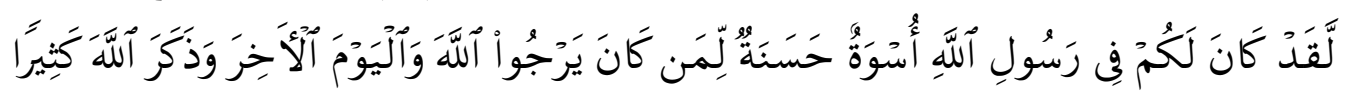

\footnotetext{
${ }^{8}$ Alhamdani, Risalah Nikah: Hukum Perkawinan Islam, h. 80.

${ }^{9}$ Kemeterian Agama, Al-Qur'an dan Terjemahannya

${ }^{10}$ Alhamdani, Risalah Nikah: Hukum Perkawinan Islam, h. 79.

${ }^{11}$ Agus Mustofa, Poligami Yuuk, h. 226.

${ }^{12}$ Kemeterian Agama, Al-Qur'an dan Terjemahannya.
} 
Terjemahnya:

Sesungguhnya telah ada pada (diri) Rasulullah itu suri teladan yang baik bagimu (yaitu) bagi orang-orang yang mengharap (rahmat) Allah dan (kedatangan) hari kiamat dan dia banyak menyebut Allah. ${ }^{13}$

Ketiga, Rasulullah diutus untuk melindungi dan mengangkat martabat kaum wanita, anak-anak yatim, para budak, dan kaum tertindas lainnya. Ini dalam QS. al-Nisā (4): 127

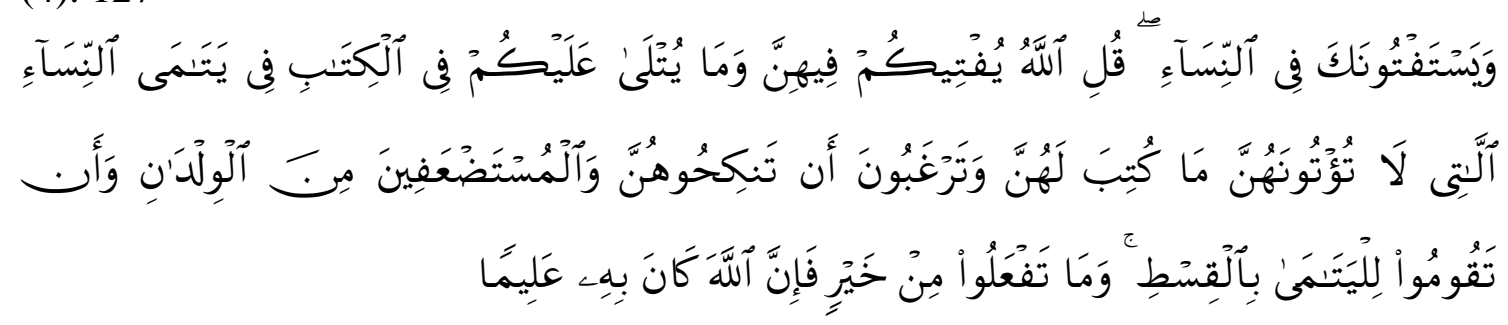

Terjemahnya:

Dan mereka meminta fatwa kepadamu tentang para wanita. Katakanlah: "Allah memberi fatwa kepadamu tentang mereka, dan apa yang dibacakan kepadamu dalam al-Qur'an tentang para wanita yatim yang kamu tidak memberikan kepada mereka apa yang ditetapkan untuk mereka, sedang kamu ingin mengawini mereka dan tentang anak-anak yang masih dipandang lemah. Dan (Allah menyuruh kamu) supaya kamu mengurus anak-anak yatim secara adil. Dan kebajikan apa saja yang kamu kerjakan, maka sesungguhnya Allah adalah Maha Mengetahuinya. ${ }^{14}$

Keempat, Rasulullah menyuruh umatnya untuk berumah tangga untuk membentuk keluarga yang sejahtera, bahagia dan menumbuhkan generasi Islami yang kuat dimasa depan. Bukan semata-mata untuk menyalurkan fitrah seksnya.

Kelima, dengan banyaknya wahyu yang diturunkan kepada Rasulullah saw. maka perlu mengkaji agar makna yang terkandung menjadi jelas dan dicontohkan secara nyata sesuai dengan makna kandungannya. Dengan mengetahui makna yang tersirat, maka dengan jelas terlihat alasan-alasan dibalik praktik poligami yang dilakukan Rasulullah tersebut.

Praktik poligami Rasulullah saw. secara jelas tidak berdasar pada kebutuhan biologis, atau hanya untuk mendapatkan keturunan. Dalam perkawinan Rasulullah, poligami yang beliau lakukan dengan mengawini perempuan yang sudah lanjut usia kecuali Aisyah, dan juga poligami dilakukan bukan pada kondisi atau situasi yang normal, melainkan dalam situasi perang jihad, perjuangan dan pengabdian yang tujuan utamanya untuk berdakwa dan menegakkan syiar Islam. ${ }^{15}$

Poligami yang dilakukan Rasulullah bahkan lebih dari empat istri, dalam alQur'an juga secara tegas memberikan kekhususan dan pembatasan poligami Rasulullah, agar tidak ditiru oleh umat Islam secara sembarangan. Dengan pembahasan holistik

\footnotetext{
${ }^{13}$ Kemeterian Agama, Al-Qur'an dan Terjemahannya.

${ }^{14}$ Kemeterian Agama, Al-Qur'an dan Terjemahannya.

${ }^{15}$ Muhammad Saleh Ridwan, Perkawinan Dalam Prespektif Hukum Islam dan Hukum Nasional (Makassar: Alauddin University Press, 2014), h. 59.
} 
Andi Intan Cahyani

semacam ini kita bisa memahami praktek poligami Rasulullah secara lebih proporsional. $^{16}$

Dengan mengetahui sejarah poligami yang dilakukan Rasulullah saw. berserta alasan serta tujuannya yang mempunyai prinsip mulia,secara jelas sangat jauh berbeda dengan poligami yang berkembang dalam kehidupan masyarakat pada umumnya, yang melupaka unsur keadilan di dalamnya sebagai syarat utama dalam melakukan poligami tetapi mengedepankan pemenuhan nafsu biologis. ${ }^{17}$

\section{Poligami dalam Berbagai Sudut Pandang}

Firman Allah dalam QS. al-Nisā/4: 3 yang menjadi dasar rujukan diperbolehkannya melakukan poligami menuai perbedaaan pendapat. Ulama yang pada umumnya memperbolehkan melakukan praktik poligami tidaklah cenderung memudahmudahkan, kebolehan tersebut mempunyai syarat yang sangat ketat. Sedangkan yang cenderung melarang praktik poligami berasal dari ulama-ulama kontmporer. Menurut mereka dalam Islam sesungguhnya menganut prinsip monogami dan melarang keras terjadinya poligami karena bersumber dari kebiasaan bangsa Arab pra-Islam yang memberikan status dan kedudukan lebih dominan kepada laki-laki. ${ }^{18}$

Berikut perkataan ulama tafsir tentang tafsir ayat tersebut, antara lain: ${ }^{19}$

1. Ibnu Katsir dalam menafsirkan ayat tersebut mengutip perkataan Imam Syafi'i, yaitu: "Sunnah Rasulullah saw yang menjadi penjelasan bagi firman Allah sesungguhnya menunjukkan kepada tidak boleh bagi seseorang selain Rasulullah saw menghimpun istri-istri lebih banyak dari empat orang". Selanjutbya Ibnu Katsir berkata: "Perkataan Syafi'i ini merupakan jimak para ulama kecuali pendapat yang diceritakan dari suatu kelompok Syi'ah yang membolehkan menghimpun istri-istri lebih banyak dari empat sampai dengan sembilan orang". Ayat tersebut bermakna bahwa apabila kamu khawatir tidak dapat berlaku adil terhadap perempuan yatim jika kamu mengawininya, maka kawinilah wanita merdeka satu sampai empat, atau budak-budak perempuan yang kamu miliki.

2. Al-Qurthubi dalam tafsirnya bahwa memang benar ayat tersebut secara khusus berbicara tentang perempuan yatim, namun secara hukum hal itu berlaku untuk seluruh perempuan (baik yatim dan tidak yatim). Pelajaran itu diambil dari keumuman lafaz, bukan dari kekhususan sebab. Sehingga jelass bagi kita bahwa alQur'an memperbolehkan untuk poligami dengan syarat keadilan.

3. Al-Khasin dalam menafsirkan ayat di atas berkata "Yakni kamu tidak sekali-kali mampu berlaku adil di antara istri-istrimu dan kecenderungan hati, karena yang demikian itu termasuk dalam hal-hal yang kamu tidak akan kuasa dan mampu atasnya".

4. Dalam tafsir Jalalain dikatakan: "kamu sekali-kali tidak akan dapat berlaku adil diantara istri-istrimu dalam hal cinta walaupun kamu sangat ingin berbuat demikian, karena itu janganlah kamu cenderung dalam semua kecenderungan kepada istri yang kamu cintai dalam hal pembagian malam dan nafkah.

\footnotetext{
${ }^{16}$ Agus Mustofa, Poligami Yuuk, h. 230-232.

${ }^{17}$ Muhammad Saleh Ridwan, Perkawinan Dalam Prespektif Hukum Islam dan Hukum Nasional, h.

${ }^{18}$ Nasaruddin Umar, Ketika fikih Membela Perempuan, h. 129-.130.

${ }^{19}$ Muhammad Yahya, Poligami Dalam Perspektif Nabi saw, h. 6.
} 59. 
Kesimpulannya, bagi seorang suami pelaku poligami yang cinta dan kasi sayangnya cenderung kepada salah seorang istrinya tersebut diperbolehkan, kecuali dalam hal pembagian nafkah dan waktu tetap manjadi kategori wajib bagi suami untuk berlaku adil kepada istri-istrinya. ${ }^{20}$

Sayyid Muhammad Rasyid Ridha mengatakan bahwa hukum poligami itu mubah, sebab dalam hukum Islam secara mutlak tidak mengharamkan dan tidak pula memberikan dispensasi (kelonggaran), dengan mempertimbangkan bahwa watak yang dimiliki laki-laki mampu dalam berbagi bidang, termasuk dalam perkawinan yang cenderung melakukan poligami. Sehingga dalam melakukannya harus terlebih dahulu mempertimbangkan mudharatnya. ${ }^{21}$

Menurut Imam al-Ghazali, poligami dalam Islam memiliki aturan yang khusus. Seperti halnya dalam Islam yang menganjurkan untuk berpuasa bagi laki-laki bujang yang belum mampu melakukan pernikahan, sama dengan jika laki-laki tidak mampu untuk berlaku adil maka jangan memaksakan diri melakukan poligami ${ }^{22}$

\section{Hukum Poligami di Indonesia}

Negara Indonesia sebagai negara hukum, memiliki peraturan tesendiri mengenai perkawinan, yang tertuang dalam UU No. 1 Tahun 1974. Dalam pasal 3 (1) UU No. 1/1974 undang-undang tersebut secara jelas bahwa hukum perkawinan di Indonesia menganut asas monogami yang diperuntukkan bagi laki-laki maupun bagi perempuan. Akan tetapi, dalam undang-undang ini pula terdapat pengecualian, seorang suami bisa beristri lebih dari satu orang apabila ada izin dari pihak yang bersangkutan, dalam hal ini istri terdahulu. Adanya pengecualian ini berlandaskan pada agama yang tidak mengharamkan praktik poligami. ${ }^{23}$

Berkaitan dengan undang-undang yang berlaku di Indonesia yang tidak memberikan kelonggaran terhadap poligami, kecuali dalam keadaan yang mendesak sehingga tidak ada jalan lain yang bisa ditempuh, sejalan dengan ajaran Islam yang memberikan syarat ketat terhadap calon pelaku poligami. Oleh karena itu, jika syaratsyarat yang ditentukan telah terpenuhi maka pelaku poligami tidak akan mengalami kesulitan dalan berumah tangga akibat dari tuntutan istri-istrinya. ${ }^{24}$

Peraturan Pemerintah No. 9 Tahun 1975 tentang Pelaksanaan UU No. 1/1974) juga secara tegas tdiak memperbolehkan poligami kecuali jika pihak yang bersangkutan memberikan izin persetujuan. ${ }^{25}$ Begitu pula dalam Kompilasi Hukum Islam (KHI) Pasal 55 dinyatakan bahwa laki-laki bisa beristri lebih dari satu orang sampai empat orang dengan syarat suami harus mampu berlaku adil terhadap istri-istri dan anak-anaknya, dan apabila syarat tersebut dikhawatirkan tidak terpenuhi maka suami dilarang beristri lebih dari satu. ${ }^{26}$

\footnotetext{
${ }^{20}$ Muhammad Yahya, Poligami Dalam Perspektif Nabi saw, h. 13.

${ }^{21}$ Umar Syihab, Hukum Islam dan Transformasi Pemikiran (semarang: Toha Putra Group, 1996), h. 120 .

${ }^{22}$ Muhammad Yahya, Poligami Dalam Perspektif Nabi saw, h. 113.

${ }^{23}$ Muhammad Saleh Ridwan, Perkawinan Dalam Prespektif Hukum Islam dan Hukum Nasional, h. 86-87.

${ }^{24}$ Umar Syihab, Hukum Islam dan Transformasi Pemikiran, h. 120-121.

${ }^{25}$ Muhammad Yahya, Poligami Dalam Perspektif Nabi saw, h. 246

${ }^{26}$ Amiur Nuruddin dan Azhari Akmal Tarigan, Hukum Perdata Islam di Indonesia: Studi Kritis Perkembangan Hukum Islam dari Fikih, UU No. 1/1974 sampai KHI, h. 166.
} 
Dari beberapa dasar dan aturan yang telah dikemukakan dapat dipahami bahwa asas perkawinan adalah monogamy yang bersifat mutlak, tetapi monogami terbuka, sebab menurut pasal 3 (1) UU No. 1/1974 dikatakan bahwa seorang suami hanya boleh mempunyai seorang istri begitu pula sebaliknya. Tetapi, pada pasal 3 (2) UU No. 1/1974 yang menyatakan bahwa "pengadilan dapat memberikan izin kepada seorang suami untuk beristri lebih dari satu orang apabila dikehendaki oleh pihak-pihak yang bersangkutan. Dengan adanya ayat (20 ini berarti Undang-Undang ini menganut asas monogami terbuka, oleh karena itu tidak tertutup kemungkinan dalam keadaaan tertentu seorang suami melakukan poligami yang tentunya dengan pengawasan pengadilan. ${ }^{27}$

Melihat beberapa peraturan hukum yang berlaku di Indonesia, tidak ada satupun peraturan yang melarang secara tegas pelaku poligami. Karena, jika dilihat peraturanperaturan tersebut memberikan cela dengan syarat adanya persetujuan dari pihak yang bersangkutan, dalam hal ini istri.

\section{Rukun, Syarat serta Hikmah Berpoligami}

Para ulama menyebutkan dua syarat yang Allah swt. sebut dalam al-Qur'an ketika seorang lelaki hendak berpoligami, dan syarat lainnya yang disebutkan dalam hadist Rasulullah saw.: ${ }^{28}$

1. Jumlah istri paling banyak adalah empat, dan tidak boleh lebih.

2. Bisa berbuat dan berlaku adil antara istri-istrinya.

3. Adanya kemampuan jasmani dan nafkah dalam bentuk harta.

Ketiga syarat yang dikemukakan di atas harus terpenuhi. Baik itu syarat satu, dua dan tiga membolehkan seorang lelaki yang hendak berpoligami untuk menikahi sampai empat perempuan secara adil. Hukum berlaku adil yang disebut di atas adalah fardhu atau wajib. Jadi, meninggalkannya adalah dosa dan pelanggaran. ${ }^{29}$

Alasan dalam berpoligami juga harus jelas dan mampu diterima oleh akal. Maka, dapat dikemukakan uraian yang menjadi bahan berfikir terhadap dibolehkannya berpoligami sebagai berikut: ${ }^{30}$

1. Poligami harus diakukan dalam kondisi tertentu,artinya tidak dalam kondisi normal. misalnya jika istri sudah lanjut usia atau sakit, sehingga dikhawatirkan suami tidak bisa menjaga kehormatan dirinya jika tidak melakukan poligami.

2. Pernikahan merupakan sebab terjalinnya hubungan (kekeluargaan) dan keterikatan di antara sesama manusia. Dengan kata lain, melakukan poligami menjadi sebab terjalinnya hubungan dan kedekatan antara banyak keluarga, dan ini pula salah satu sebab poligami yang dilakukan oleh Rasulullah saw.

3. Poligami merupakan sebab terjaganya kehormatan sejumlah besar wanita dan terpenuhinya kebutuhan hidup mereka yang berupa nafkah, tempat tinggal, memiliki keturunan dan anak yang banyak, dan ini merupakan tuntutan syariat.

4. Laki-laki yang memiliki nafsu syahwat yang tinggi, sehingga bawaannya tidak cukup baginya mempunyai seorang istri, sedangkan dia tidk mau terjerumus dalam hal-hal yang melanggar syariat.

\footnotetext{
${ }^{27}$ Muhammad Yahya, Poligami Dalam Perspektif Nabi saw, h. 247.

${ }^{28}$ Muhammad Yahya, Poligami Dalam Perspektif Nabi saw, h. 134.

${ }^{29}$ Muhammad Yahya, Poligami Dalam Perspektif Nabi saw, h. 134.

${ }^{30}$ Muhammad Yahya, Poligami Dalam Perspektif Nabi saw, h. 139.
} 
5. Terkadang setelah menikah istri mandul, sehingga memilih poligami daripada perceraian.

Al-Jurjani dalam kitabnya, Hikmah al-Tasyri' wa Falsafatuhu menjelaskan ada empat hikmah yang dikandung poligami. Pertama, kebolehan poligami yang dibatasi sampai empat orang yang menunjukkan bahwa manusia sebenarnya terdiri dari empat campuran dalam tubuhnya. Jadi menurutnya, sangatlah pantas laki-laki itu beristri empat. Kedua, batasan empat juga sesuai dengan empat jenis mata pencaharian lakilaki; pemerintahan, perdagangan, pertanian dan industry. Ketiga, bagi seorang suami yang memiliki empat orang istri berarti ia mempunyai waktu senggang selama tiga hari dan ini merupakan waktu yang cukup untuk mencurahkan kasih sayang. ${ }^{31}$

Adalah al-Athar dalam bukunya Ta'addud al-Zawzat mencatat empat dampak negative poligami. Pertama, poligami dapat menimbulkan kecemburuan di antara para istri. Kedua, menimbulkan rasa kekhawatiran istri kalau-kalau suami tidak dapat bersikap bijaksana dan adil. Ketiga, anak-anak yang lahir dari ibu yang berlainan sangat rawan perkelahian, permusuhan dan saling cemburu. Keempat, kekacauan dalam bidang ekonomi. Bisa saja pada awalnya suami memiliki kemampuan untuk poligami, namun bukan mustahil suatu saat akan mengalami kebangkrutan, maka yang akan menjadi korban akan lebih banyak. ${ }^{32}$

\section{PENUTUP}

\section{Kesimpulan}

Poligami adalah laki-laki memiliki istri lebih dari satu sampai empat orang. Dalam pandangan Islam, poligami boleh dilakukan jika memenuhi syarat yang sudah jelas dalam al-Qur'an yaitu, mampu berlaku adil. Adil yang dimaksud disini meliputi beberapa bagian, yaitu: adil dalam pembagian waktu, adil dalam nafkah, adil dalam tempat tinggal dan adil dalam biaya anak.

Poligami Rasulullah berbeda dengan poligami yang kita lihat sekarang ini. Praktek poligami Rasulullah di sini bukan berlandaskan ebutuhan biologis, tetapi ada beberapa pertimbangan diantaranya ingin memberi kehormatan untuk janda, mengangkat derajat para janda dan wanita yang menawarkan dirinya untuk dinikahi. Dalam masa sekarang poligami hanya berlandaskan kebutuhan biologis, dan melupakan unsur keadilan di dalamnya.

\section{Implikasi}

Dengan adanya makalah ini diharapkan mampu untuk mengetahui hukum poligami yang sebenarnya, dengan mempertimbangkan praktik poligami yang dilakukan Rasulullah saw disertai dengan pertimbangan beberapa sudut pandang dari berbagai ulama.

\footnotetext{
${ }^{31}$ Amiur Nuruddin dan Azhari Akmal Tarigan, Hukum Perdata Islam di Indonesia: Studi Kritis Perkembangan Hukum Islam dari Fikih, UU No. 1/1974 sampai KHI, h. 160.

${ }^{32}$ Amiur Nuruddin dan Azhari Akmal Tarigan, Hukum Perdata Islam di Indonesia: Studi Kritis Perkembangan Hukum Islam dari Fikih, UU No. 1/1974 sampai KHI, h. 161.
} 


\section{DAFTAR PUSTAKA}

\section{Al-Qur'an al-Karim}

Alhamdani, Risalah Nikah: Hukum Perkawinan Islam. Yogyakarta: PT. RajaGrafindo Persada, 1972.

Yahya, Muhammad. Poligami Dalam Perspektif Nabi saw. Makassar: Alauddin University Perss, 2013.

Nuruddin, Amiur dan Azhari Akmal Tarigan, Hukum Perdata Islam di Indonesia: Studi Kritis Perkembangan Hukum Islam dari Fikih, UU No. 1/1974 sampai KHI. Cet. V. Jakarta: Kencana Prenadamedia Group, 2014.

Mustofa, Agus. Poligami Yuuk! (Surabaya: PADMA Press.

Umar, Nasaruddin. Ketika fikih Membela Perempuan. Jakarta: PT. Gramedia, 2014.

Saleh Ridwan, Muhammad. Perkawinan Dalam Prespektif Hukum Islam dan Hukum Nasional. Makassar: Alauddin University Press, 2014.

Syihab, Umar. Hukum Islam dan Transformasi Pemikiran, semarang: Toha Putra Group, 1996. 